\title{
Epidemiology of asthma, allergy and bronchial hyperresponsiveness in sports
}

\author{
T. Haahtela*, K. Larsson ${ }^{\#}$, S. Bonini" \\ *Dept of Allergy, Skin and Allergy Hospital, Helsinki University Central Hospital, Helsinki, Finland, ${ }^{*}$ Unit \\ of Lung and Allergy Research, National Institute of Environmental Medicine, IMM Karolinska Insitituet, \\ Stockholm, Sweden. “IRCCS San Raffaele, Rome, and Second University of Naples, Naples, Italy.
}

Correspondence: T. Haahtela, Dept of Allergy, Skin and Allergy Hospital, Helsinki University Central Hospital, FIN-00250 Helsinki, Finland. Fax: 385 947186500; E-mail: tari.haahtela@hus.fi

Asthma has a higher prevalence in athletes compared with the general population. In summer sport events, the prevalence ranges 3.7-22.8\%, as reviewed by HeLENIUS and HAAHTELA [1]. In winter sport events, the occurrence is even higher, ranging $2.8-54.8 \%$ (table 1) [2-8]. A total of $17 \%$ of 253 Finnish elite summer sport athletes used asthma medication, most commonly inhaled $\beta_{2}$-agonists [1]. Also, $17 \%$ of the USA Winter Olympic Team (Nagano, Japan) were current users of asthma medication [5], while the figure was twice as high (36\%) amongst Swedish cross-country skiers [2]. In a Swedish study in upper secondary schools for young skiers, $15 \%$ had phsysician-diagnosed asthma and $18 \%$ were treated with anti-asthma drugs compared with $6 \%$ and $7 \%$, respectively, amongst the controls [9].

\section{Occurrence of bronchial hyperresponsiveness}

Bronchial hyperresponsiveness (BHR) is correlated with clinical asthma symptoms, but the relationship is not straight forward. LARSSON et al. [2] observed that 23 out of 42 (54.8\%) cross-country skiers had BHR and asthma symptoms. Two skiers had BHR without symptoms and 17 had symptoms, but no BHR. LEUPPI et al. [7] found that 35\% of Swiss ice hockey players had BHR, but clinical asthma was diagnosed in 19\% and exercise-induced bronchospasm (EIB) in $11 \%$ of them. The respective figures for BHR, clinical asthma and EIB were lower in floor ball players: $21 \%, 4.2 \%$ and $4.2 \%$.

SuE-CHU et al. [3] reported that in cross-country skiers the figures for BHR and clinical asthma were closer to each other: $14 \%$ and $12 \%$ in Norway, and $43 \%$ and $42 \%$ in Sweden, respectively. KARJALAINEN et al. [10] studied 40 young elite skiers and 12 healthy control subjects. BHR to methacholine was found in $30(75 \%)$ of the skiers, and one-third of them had symptoms suggestive of asthma.

BHR is also prevalent in swimmers. ZwICK et al. [11] found competitive swimmers to have BHR significantly more often than control subjects (78\% versus $36 \%)$. In another study, BHR was detected in $60 \%$ of swimmers and in $12 \%$ of nonswimming athletes [12]. The prevalence of BHR was higher in swimmers $(36 \%)$ than in speed and power athletes $(18 \%)$ and in long-distance runners $(9 \%)$ [13]. A "healthy runner effect" certainly takes place, especially in long-distance runners. BHR was significantly associated with atopy.

Conclusions of the associations are problematic in cross-sectional studies because dynamic variables fluctuate over time depending on various factors. HeIR et al. [14] observed that acute respiratory tract infections were associated with a transient increase

Eur Respir Mon, 2005, 33, 1-4. Printed in UK - all rights reserved. Copyright ERS Journals Ltd 2005; European Respiratory Monograph; ISSN 1025-448x. ISBN 1-904097-22-7.

Purchased by ,

From: European Respiratory Society Publications (reader.ersjournals.com) 
Table 1. - Prevalence of asthma amongst highly trained winter sports athletes

\begin{tabular}{|c|c|c|c|c|}
\hline Group of athletes & Subjects $n$ & Method & Prevalence \% & First author [Ref.] \\
\hline Cross-country skiers & 42 & $\begin{array}{l}\text { Questionnaire, spirometry, } \\
\text { methacholine challenge }\end{array}$ & 54.8 & LARSSON [2] \\
\hline Cross-country skiers & 171 & $\begin{array}{l}\text { Questionnaire, spirometry, } \\
\text { methacholine challenge }\end{array}$ & $\begin{array}{l}12 \text { (Norway) } \\
42 \text { (Sweden) }\end{array}$ & SUE-CHU [3] \\
\hline Figure skaters & 124 & Exercise test & $\begin{array}{l}35 \text { (exercise-induced } \\
\text { bronchospasm) }\end{array}$ & MANNIX [4] \\
\hline Ice hockey players & \# & $\begin{array}{c}\text { Questionnaire, spirometry, } \\
\text { methacholine challenge, } \\
\text { exercise test }\end{array}$ & $\begin{array}{c}19.2 \\
11.5 \text { (exercise-induced } \\
\text { bronchospasm) }\end{array}$ & LEUPPI [7] \\
\hline Ice hockey players & 88 & $\begin{array}{l}\text { Questionnaire, spirometry, } \\
\text { histamine challenge }\end{array}$ & $\begin{array}{c}22 \text { (total asthma) } \\
13 \text { (current asthma) }\end{array}$ & LUMME [8] \\
\hline $\begin{array}{l}1998 \text { USA Winter } \\
\text { Olympic team }\end{array}$ & 196 & Questionnaire & $\begin{array}{c}21.9 \\
60.7 \text { (cross-country, etc.) } \\
24 \text { (alpine, etc.) } \\
2.8 \text { (bobsleigh, etc.) }\end{array}$ & WEILER [5] \\
\hline $\begin{array}{l}1998 \text { USA Winter } \\
\text { Olympic team }\end{array}$ & \# & $\begin{array}{l}\text { Exercise challenge, } \\
\text { spirometry }\end{array}$ & $\begin{array}{l}23 \text { (all, exercise-induced } \\
\text { bronchospasm) } \\
50 \text { (cross-country) }\end{array}$ & WILBER [6] \\
\hline
\end{tabular}

\#: Source population $n=196$.

in BHR in athletes performing physical training, but not in nonactive control subjects. Exercise and breathing cold air causes transient BHR even in asthmatic nonathletes $[15,16]$.

\section{Occurrence of eosinophilic airway inflammation}

Asthma symptoms and lung function abnormalities, including BHR, are a consequence of airway inflammation, which in asthma is predominately of an eosinophilic type. However, in athletes a mixed type of eosinophilic and neutrophilic airway inflammation has been shown to affect ice hockey players, cross-country skiers and elite swimmers $[8,10,17]$.

Sputum eosinophilia ( $>2 \%$ of the differential cell count) affected one-fifth of highly trained swimmers $[17,18]$ and one-tenth of ice hockey players [8]. Those swimmers with exercise-induced bronchial symptoms had significantly higher sputum eosinophil cell counts (mean 7.6\%) than the symptom-free swimmers (mean 0.7\%) [17]. After 5-yr follow-up, sputum eosinophilia was detected in 38\% (6\% at baseline) of those swimmers who continued their active career, and in $8 \%$ (19\% at baseline) of those who had stopped intensive training [18].

KARJALAINEN et al. [10] showed that the number of activated eosinophils, Tlymphocytes and macrophages in the subepithelial tissue are much higher in crosscountry skiers than in sedentary control subjects. Elite swimmers have shown increased concentrations of eosinophil peroxidase (EPO) and human neutrophil lipocaline (HNL) in the supernatant of induced sputum samples as compared with control subjects, which suggests that both eosinophils and neutrophils are more activated in swimmers than in controls [17].

\section{Type of training as a risk factor}

Highly trained athletes are repeatedly and strongly exposed to cold air during winter training and to many inhalant irritants and allergens all year long. The type of training has been associated with the occurrence of bronchial symptoms, BHR and asthma in elite athletes $[13,19]$. 
Asthma is most commonly found in athletes performing endurance events, such as cross-country skiing, swimming or long-distance running. Mild asthma (defined usually as increased BHR and asthma symptoms) is most common in endurance athletes, such as cross-country skiers $(14-55 \%)[2,3]$, swimmers $(13-44 \%)[13,17,18,20]$ and longdistance runners $(15-24 \%)[13,21]$. Also, speed and power athletes, e.g. ice hockey players $(15-19 \%)[6,7,8]$, and track and field athletes $(16 \%)[13,19]$, have a somewhat increased risk of asthma.

\section{Atopy as a risk factor}

Evidence for an increase in immunoglobulin E-mediated allergy has been shown in the general population $[22,23]$. It seems that an increasing proportion of young athletes are atopic $[8,13]$ and suffer from symptoms caused by inhalant allergens. Hay fever, the most clear-cut atopic condition, is more common in summer sports athletes than in control subjects $[13,24]$.

Atopic disposition is a major risk factor along with the type of training. Risk of asthma is closely associated with atopy and its severity amongst athletes. When the risk factors "sporting event" and "atopy" were combined in a logistic regression model, the relative risk of asthma was surprisingly large: 25 fold in atopic speed and power athletes, 42 fold in atopic long-distance runners, and 97 fold in atopic swimmers compared with nonatopic control subjects [13].

\section{Outcome of asthma and asthma-like symptoms}

Outcome of asthma in athletes has not been widely studied. In swimmers who stopped intensive training, BHR and asthma attenuated or even disappeared, whilst symptoms increased and eosinophilic airway inflammation was aggravated in swimmers who remained active during the 5-yr follow-up, irrespective of asthma treatment [18]. Thus, asthma in athletes is at least partly reversible, and intensive training seems to cause airway inflammation and asthmatic symptoms in susceptible individuals.

\section{Summary}

Clinical asthma, exercise-induced bronchospasm and bronchial hyperresponsiveness are more common in competitive athletes compared with the general population. Various atopic conditions (e.g. pollen allergy) seem to be more common in summer sports athletes than in control subjects. Type of training and atopy are major risk factors for lower airway symptoms. Asthma is most commonly found in athletes performing endurance events, such as cross-country skiing, swimming or long-distance running. These athletes are repeatedly and strongly exposed to cold air and many inhalant irritants and allergens all year long. In symptomatic athletes, a mixed type of eosinophilic and neutrophilic airway inflammation often occurs leading in some individuals to functional abnormalities. Asthmatic symptoms in athletes are usually mild and at least partly reversible as they may disappear in those who stop intensive training.

Keywords: Allergy, asthma, bronchospasm, bronchial hyperresponsiveness, epidemiology, exercise. 


\section{References}

1. Helenius I, Haahtela T. Allergy and asthma in elite summer sports athletes. J Allergy Clin Immunol 2000; 106: 444-452.

2. Larsson K, Ohlsen P, Larsson L, Malmberg P, Rydström P, Ulriksen H. High prevalence of asthma in cross-country skiers. BMJ 1993; 307: 1326-1329.

3. Sue-Chu M, Larsson L, Bjermer L. Prevalence of asthma in young cross-country skiers in central Scandinavia: differences between Norway and Sweden. Respir Med 1996; 90: 99-105.

4. Mannix ET, Farber MO, Palange P, Galassetti P, Manfredi F. Exercise-induced asthma in figure skaters. Chest 1996; 109: 312-315.

5. Weiler JM, Ryan EJ 3rd. Asthma in United States Olympic athletes who participated in 1998 Olympic Winter Games. J Allergy Clin Immunol 2000; 106: 267-271.

6. Wilber RL, Rundell KW, Szmedra L, Jenkinson DM, Im J. Incidence of exercise-induced bronchospasm in Olympic Winter sport athletes. Med Sci Sports Exerc 2000; 32: 732-737.

7. Leuppi JD, Kuhn M, Comminot C, Rheinhart WH. High prevalence of bronchial hyperresponsivness and asthma in ice hockey players. Eur Resp J 1998; 12: 13-16.

8. Lumme A, Haahtela T, Öunap J, et al. Airway inflammation, bronchial hyperresponsiveness, and asthma in elite ice hockey players. Eur Respir J 2003; 22: 113-117.

9. Larsson L, Hemmingsson P, Boethius G. Self-reported obstructive airway symptoms are common in young cross-country skiers. Scan J Med Sci Sports 1999; 4: 124-127.

10. Karjalainen EM, Laitinen A, Sue-Chu M, Altraja A, Bjermer L, Laitinen LA. Evidence of airway inflammation and remodeling in ski athletes with and without bronchial hyperresponsiveness to methacholine. Am J Respir Crit Care Med 2000; 161: 2086-2091.

11. Zwick H, Popp W, Budik G, Wanke T, Rauscher H. Increased sensitization to aeroallergens in competitive swimmers. Lung 1990; 168: 111-115.

12. Potts J. Factors associated with respiratory problems in swimmers. Sports Med 1996; 21: 256-261.

13. Helenius IJ, Tikkanen HO, Sarna S, Haahtela T. Asthma and increased bronchial responsiveness in elite athletes: atopy and sport event as risk factors. J Allergy Clin Immunol 1998; 101: 646-652.

14. Heir T, Aanestad G, Carlsen KH, Larsen S. Respiratory tract infection and bronchial responsiveness in elite athletes and sedentary control subjects. Scand J Med Sci Sports 1995; 5: 94-99.

15. Suzuki S, Chonan T, Sasaki H, Takishima T. Bronchial hyperresponsiveness to methacholine after exercise in asthmatics. Ann Allergy 1985; 54: 136-141.

16. Dosman JA, Hodgson WC, Cockcroft DW. Effect of cold air on the bronchial response to inhaled histamine in patients with asthma. Am Rev Respir Dis 1991; 144: 45-50.

17. Helenius IJ, Rytilä P, Metso T, Haahtela T, Venge P, Tikkanen HO. Respiratory symptoms, bronchial responsiveness and cellular characteristics of induced sputum in elite swimmers. Allergy 1998; 53: 346-352.

18. Helenius I, Rytilä P, Sarna S, et al. Effect of continuing or finishing high-level sports on airway inflammation, bronchial hyperresponsiveness, and asthma. A prospective follow-up study of 42 elite swimmers. J Allergy Clin Immunol 2002; 109: 962-968.

19. Helenius IJ, Tikkanen HO, Haahtela T. Association between type of training and risk of asthma in elite athletes. Thorax 1997; 52: 157-160.

20. Langdeau JB, Turcotte H, Bowie DM, Jobin J, Desgagne P, Boulet LP. Airway hyperresponsiveness in elite athletes. Am J Respir Crit Care Med 2000; 161: 1479-1484.

21. Tikkanen HO, Helenius I. Asthma in runners. BMJ 1994; 309: 1087.

22. Kosunen TU, Höök-Nikanne J, Salomaa A, Sarna S, Aromaa A, Haahtela T. Increase of allergenspecific immunoglobulin E antibodies from 1973 to 1994 in a Finnish population and a possible relationship to helicobacter pylori infections. Clin Exp Allergy 2002; 32: 373-378.

23. Krause T, Koch A, Friborg J, Poulsen LK, Kristensen B, Melbye M. Frequency of atopy in the arctic in 1987 and 1998. Lancet 2002; 360: 691-692.

24. Katelaris CH, Carrozzi FM, Burke TV, Byth K. A springtime Olympics demands special consideration for allergic athletes. J Allergy Clin Immunol 2000; 106: 260-266. 